\title{
Effect of aluminium on endosperm reserve mobilization in germinating rice grains
}

\author{
J.-W. WANG and C.H. KAO* \\ Department of Agronomy, National Taiwan University, Taipei, Taiwan 106, Republic of China
}

\begin{abstract}
The effect of $\mathrm{AlCl}_{3}$ on endosperm reserve mobilization of rice grains or dehulled rice grains during germination was investigated. $\mathrm{AlCl}_{3}$ had no effect on grain fresh and dry masses, protein and starch contents, and $\alpha$-amylase and protease activities in endosperm of germinating rice grains. However, when dehulled rice grains were treated with $\mathrm{AlCl}_{3}, \mathrm{AlCl}_{3}$ inhibited the decrease in fresh mass, dry mass, and starch and protein contents, and the increase in $\alpha$-amylase and protease activities in endosperm. Evidence is provided to show that the hull is a barrier against influx of Al to endosperm.
\end{abstract}

Additional key words: $\alpha$-amylase, Oryza sativa, protease.

\section{Introduction}

Aluminium, the third most abundant element in the earth crust, has been recognized as an inhibitor factor for most crop production on acid soils which make up a large proportion of arable land in the tropical and subtropical areas. The most dramatic symptom of $\mathrm{Al}$ phytotoxicity is the reduction of root growth (Matsumoto 2000). However, the mechanisms of the root growth inhibition by $\mathrm{Al}$ have not been fully elucidated.

Cereals, such as rice and barley, store starch and protein in their endosperm cells. Starch and protein are degraded mainly by $\alpha$-amylase and protease, respectively, and are mobilized to supply sources of carbon, amino

\section{Materials and methods}

Dehulled rice (Oryza sativa L., cv. Taichung Native 1) grains or rice grains were surface-sterilised in $2.5 \%(\mathrm{v} / \mathrm{v})$ sodium hypochlorite for $15 \mathrm{~min}$, washed in distilled water, sown on moistened filter paper in a Petri dish $(20 \mathrm{~cm})$, and incubated at $37^{\circ} \mathrm{C}$. After 24-h incubation, seedlings with $2 \mathrm{~mm}$ shoots were selected and transferred to Petri dishes containing two sheets of filter paper moistened with $10 \mathrm{~cm}^{3}$ of distilled water (pH 4.0) or $0.5 \mathrm{mM} \mathrm{AlCl}_{3}$ acids and energy for the growth of embryos (Bewley 1997, Pritchard et al. 2002). Al inhibits growth of rice roots (Nishizawa 1995). Thus, it is not unreasonable to speculate that $\mathrm{Al}$ may inhibit endosperm mobilization in germinating rice grains. In a recent report, Kataoka et al. (2003) demonstrated that aluminium treatment decreased apoplast protein in soybean root tips.

In this paper, we report the effect of $\mathrm{AlCl}_{3}$ on the changes in the contents of starch and protein and the activities of $\alpha$-amylase and protease in endosperm of germinating dehulled rice grains and rice grains.

(pH 4.0) and allow to grow at $27^{\circ} \mathrm{C}$ in the dark. Distilled water or $\mathrm{AlCl}_{3}$ solution was changed every $3 \mathrm{~d}$. Each Petri dish contained 20 germinated dehulled rice grains or rice grains. Each treatment replicated 4 times.

Starch in endosperms was extracted twice with hot ethanol $(80 \%, \mathrm{v} / \mathrm{v})$. The tissue residues were suspended in $2 \mathrm{mM}$ sodium phosphate buffer ( $\mathrm{pH}$ 6.9) containing $6 \mathrm{mM} \mathrm{NaCl}$, and were boiled for $15 \mathrm{~min}$ to gelatinize the

Received 3 October 2003, accepted 10 November 2004.

Abbreviations: d.m. - dry mass, f.m. - fresh mass.

Acknowledgements: This work was supported by the National Science Council of the Republic of China, grant NSC92-2313-B-002-001.

* Corresponding author; fax: (+886) 02 23620879, e-mail: kaoch@ntu.edu.tw 
starch. Crude boiled homogenates were then used to determine starch level according to the method described previously (Hurng and Kao 1993). Briefly, crude boiled homogenates containing starch were digested for $16 \mathrm{~h}$ at $37^{\circ} \mathrm{C}$ with 25 units of Bacillus $\alpha$-amylase (Sigma-Aldrich, St. Louis, Missouri, USA) in sodium phosphate buffer. Blanks were comprised of sample aliquots and heat inactivated $\alpha$-amylase. Maltose produced from starch was determined by the dinitrosalicylic acid (Hurng and Kao 1993). Starch level is expressed as mg maltose equivalent per endosperm.

For $\alpha$-amylase extraction, endosperm was homogenised in prechilled mortar and pestle with $0.2 \mathrm{M}$ sodium acetate buffer ( $\mathrm{pH} 5.4$ ) containing $3 \mathrm{mM} \mathrm{CaCl}_{2}$ at $4{ }^{\circ} \mathrm{C}$. The homogenate was centrifuged at $12000 \mathrm{~g}$ for $20 \mathrm{~min}$ at $4{ }^{\circ} \mathrm{C}$. Crude extract was used to determine $\alpha$-amylase activities based on the method developed by Rinderknecht et al. (1967) using starch azure as substrate. The absorbance was measured by spectrophotometer (model U 2000, Hitachi, Tokyo, Japan) and one unit of enzyme activity is defined as $\Delta \mathrm{A}_{595} \mathrm{~min}^{-1}$.

\section{Results and discussion}

Grain dry mass (d.m.) decreased with duration of germination in both control as well as $\mathrm{AlCl}_{3}$-treated grains (Table 1). However, no difference on d.m. was observed between $\mathrm{H}_{2} \mathrm{O}$ - and $\mathrm{AlCl}_{3}$-treated grains. Basically, during germination no change in grain fresh mass (f.m.) was observed in $\mathrm{H}_{2} \mathrm{O}$-treated grains. Again, $\mathrm{AlCl}_{3}$ had no effect on grain f.m.

Starch is an important reserve in endosperm of rice grains. During germination, starch content in endosperm of rice grains decreased (Table 2). However, endosperm of grains treated with $\mathrm{AlCl}_{3}$ had similar starch content as that treated with distilled water during germination (Table 2). Mobilization of starch in endosperm is mediated by $\alpha$-amylase (Yu et al. 1992). Comparative study of $\alpha$-amylase activity in endosperm revealed a continuous increase in the activity of enzyme during germination similarly in both control as well as $\mathrm{AlCl}_{3}$ treated ones (Table 2).

Table 1. Effect of $\mathrm{AlCl}_{3}$ on the changes in grain fresh mass and grain dry mass in germinating rice grains. Rice grains were incubated in water ( $\mathrm{pH} 4.0$ ) or $0.5 \mathrm{mM} \mathrm{AlCl}_{3}(\mathrm{pH} 4.0$ ). Means $\pm \mathrm{SD}, n=40$.

\begin{tabular}{|c|c|c|c|c|}
\hline \multirow[t]{2}{*}{ Time $[\mathrm{d}]$} & \multicolumn{2}{|c|}{ Fresh mass [mg grain ${ }^{-1}$ ] } & \multicolumn{2}{|c|}{ Dry mass [mg grain $\left.{ }^{-1}\right]$} \\
\hline & $\mathrm{H}_{2} \mathrm{O}$ & $\mathrm{AlCl}_{3}$ & $\mathrm{H}_{2} \mathrm{O}$ & $\mathrm{AlCl}_{3}$ \\
\hline 0 & $34.4 \pm 0.07$ & & $25.4 \pm 0.19$ & \\
\hline 1 & $35.6 \pm 0.30$ & $35.4 \pm 0.16$ & $24.5 \pm 0.22$ & $24.7 \pm 0.34$ \\
\hline 3 & $35.0 \pm 0.06$ & $34.9 \pm 0.19$ & $21.9 \pm 0.20$ & $22.3 \pm 0.04$ \\
\hline 5 & $33.8 \pm 0.22$ & $33.5 \pm 0.23$ & $18.7 \pm 0.18$ & $18.7 \pm 0.27$ \\
\hline
\end{tabular}

For protease extraction, endosperms were homogenised in prechilled mortar and pestle with $10 \mathrm{mM}$ TrisHCl buffer ( $\mathrm{pH}$ 7.4) containing $10 \mathrm{mM}$ 2-mercaptoethanol at $4{ }^{\circ} \mathrm{C}$. The homogenate was centrifuged at $15000 \mathrm{~g}$ for $30 \mathrm{~min}$ at $4{ }^{\circ} \mathrm{C}$. The supernatant was used both for protein and protease assay. Protease was assayed according to the method described by Sheoran and Garg (1978). Protease activity was calculated based on $\Delta \mathrm{A}_{280} \mathrm{~min}^{-1}$. Protein was determined by the method of Bradford (1976).

For determination of $\mathrm{Al}$ content, endosperms or hulls were dried at $65{ }^{\circ} \mathrm{C}$ for $48 \mathrm{~h}$. Dried material was ashed at $550{ }^{\circ} \mathrm{C}$ for $20 \mathrm{~h}$. Ash residue was incubated with $31 \%$ (v/v) $\mathrm{HNO}_{3}$ and $17.5 \%(\mathrm{v} / \mathrm{v}) \mathrm{H}_{2} \mathrm{O}_{2}$ at $70{ }^{\circ} \mathrm{C}$ for $12 \mathrm{~h}$, and dissolved in $0.1 \mathrm{M} \mathrm{HCl}$. Al was then quantified using an atomic absorption spectrophotometer (Model AA-680, Shimadzu, Kyoto, Japan)

Statistical differences between measurements on different treatment or on different times were analyzed by Duncan's multiple range test or Student's $t$-test.

Table 2. Effect of $\mathrm{AlCl}_{3}$ on the changes in starch level and $\alpha$-amylase activity in endosperm of germinating rice grains. Rice grains were incubated in water $(\mathrm{pH} 4.0)$ or $0.5 \mathrm{mM} \mathrm{AlCl}_{3}$ (pH 4.0). Means $\pm \mathrm{SD}, n=4$.

\begin{tabular}{lllll}
\hline $\begin{array}{l}\text { Time } \\
{[\mathrm{d}]}\end{array}$ & \multicolumn{2}{l}{$\left.\begin{array}{l}\text { Starch } \\
{[\mathrm{mg} \text { endosperm }}\end{array}{ }^{-1}\right]$} & \multicolumn{2}{l}{$\alpha$-Amylase activity } \\
& \multicolumn{2}{l}{$\mathrm{H}_{2} \mathrm{O}$} & $\mathrm{AlCn}_{3}$ & \multicolumn{2}{l}{$\mathrm{H}_{2} \mathrm{O}$} & $\mathrm{AlCl}_{3}$ \\
\hline 0 & $13.3 \pm 0.20$ & & $0.22 \pm 0.004$ & \\
& & & & \\
1 & $13.5 \pm 0.45$ & $13.8 \pm 0.60$ & $0.23 \pm 0.02$ & $0.25 \pm 0.02$ \\
3 & $10.7 \pm 0.99$ & $11.4 \pm 0.15$ & $1.63 \pm 0.02$ & $1.61 \pm 0.02$ \\
5 & $7.5 \pm 0.53$ & $8.2 \pm 0.37$ & $1.66 \pm 0.02$ & $1.66 \pm 0.06$ \\
\hline
\end{tabular}

Endosperm of rice grains treated with $\mathrm{AlCl}_{3}$ had same content of proteins as that of grains treated with distilled water during germination (Table 3). During seed germination, mobilization of endosperm reserve proteins is mediated through the action of proteases (Beevers 1968, Yomo and Varner 1973). In control, protease activity increased significantly during germination (Table 3 ) and $\mathrm{AlCl}_{3}$ did not inhibit protease activity during germination (Table 3).

All these results seem to suggest $\mathrm{AlCl}_{3}$ had no effect on endosperm mobilization during germination of rice grains. This is in contrast to our previous work, in which we reported that $\mathrm{NaCl}$ markedly decreased the mobilization of starch in endosperm of germinating rice grains (Lin and Kao 1995).

Rice grain is the ripened ovary, with the lemma, palea, rachilla, sterile lemmas, and the awn, if present, firmly 


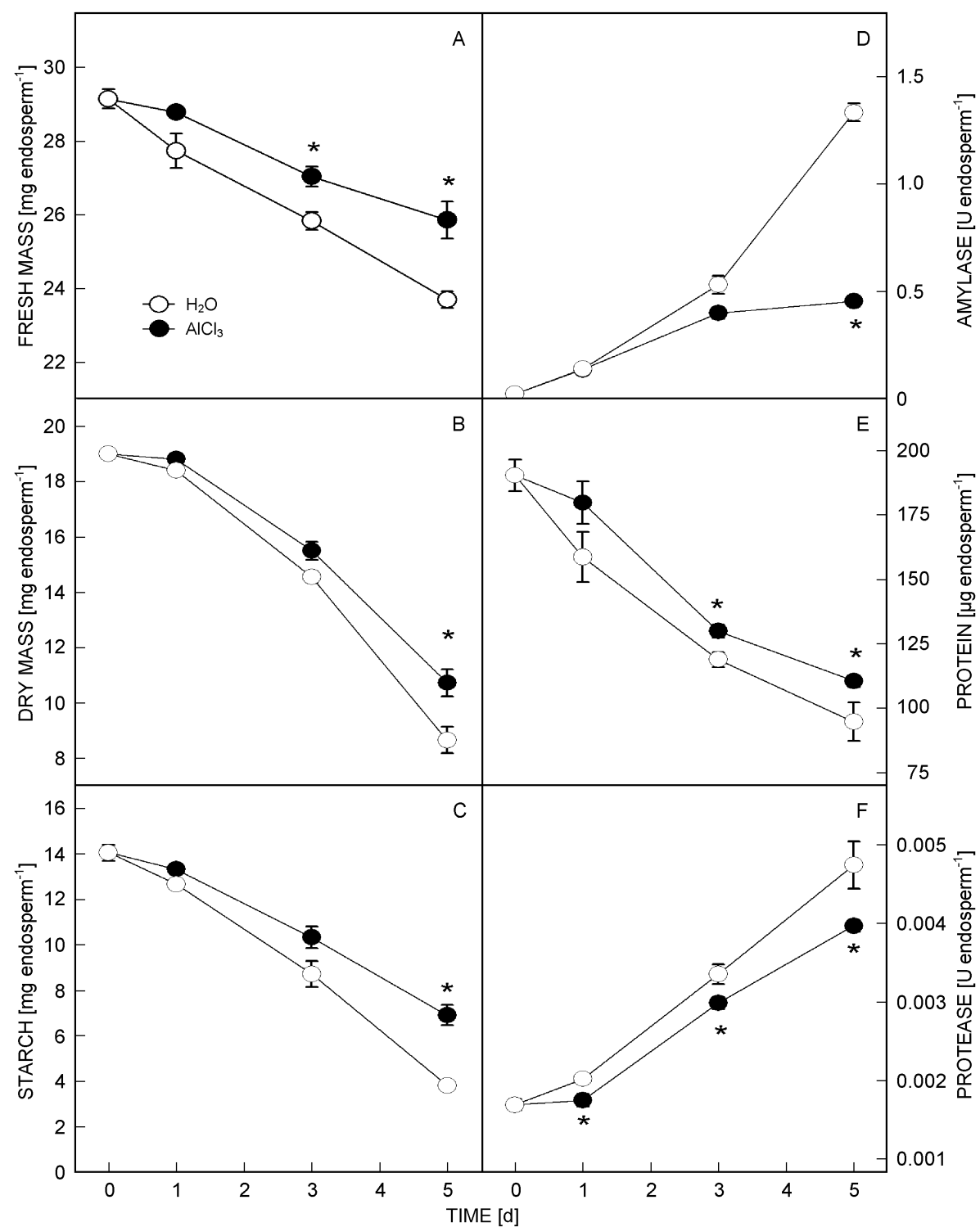

Fig. 1. Effect of $\mathrm{AlCl}_{3}$ on the changes in fresh mass (f.m.) (A), dry mass (d.m.) (B), starch content (C), amylase activity $(D)$, protein content $(E)$, and protease activity $(F)$ in endosperm of germinating dehulled rice grains. Dehulled rice grains were incubated in water ( $\mathrm{pH} 4.0$, open circles) or $0.5 \mathrm{mM} \mathrm{AlCl} 3$ ( $\mathrm{pH} 4.0$, closed circles). Means for f.m. and d.m. calculated from 40 endosperms, whereas means for the contents of starch and protein and the activities of amylase and protease calculated from 4 replicates. Asterisks indicate the differences significant between $\mathrm{H}_{2} \mathrm{O}$ and $\mathrm{AlCl}_{3}$ treatments at $P<0.05$ level calculated by Student's $t$-test.

adhered to it. The lemma and palea and their associated structures such as the sterile lemmas, rachilla, and the awn whenever present, constitute the hull or husk. It is not known whether the hull acts as a barrier against the influx of Al. To test this possibility, we determined the $\mathrm{Al}$ content in the hull and endosperm, respectively, of germinating rice grains treated with $\mathrm{AlCl}_{3}$. $\mathrm{Al}$ content in the hull increased markedly with duration of germination of rice grains treated with $\mathrm{AlCl}_{3}$ (Table 4). However, only slight increase in $\mathrm{Al}$ level was observed in the endosperm (Table 4). Al content in the endosperm of germinating dehulled rice grains treated with $\mathrm{AlCl}_{3}$ was significantly higher than in controls. Thus, the fact that $\mathrm{AlCl}_{3}$ did not
Table 3. Effect of $\mathrm{AlCl}_{3}$ on the changes in protein level and protease activity in endosperm of germinating rice grains. Rice grains were incubated in water $(\mathrm{pH} 4.0)$ or $0.5 \mathrm{mM} \mathrm{AlCl}_{3}$ (pH 4.0). Means $\pm \mathrm{SD}, n=4$.

\begin{tabular}{|c|c|c|c|c|}
\hline \multirow[t]{2}{*}{$\begin{array}{l}\text { Time } \\
\text { [d] }\end{array}$} & \multicolumn{2}{|c|}{$\begin{array}{l}\text { Protein } \\
{\left[\mu g \text { endosperm }{ }^{-1}\right]}\end{array}$} & $\begin{array}{l}\text { Protease activity } \\
{\left[\mathrm{U}_{\text {endosperm }}^{-1}\right]}\end{array}$ & \multirow[b]{2}{*}{$\mathrm{AlCl}_{3}$} \\
\hline & $\mathrm{H}_{2} \mathrm{O}$ & $\mathrm{AlCl}_{3}$ & $\mathrm{H}_{2} \mathrm{O}$ & \\
\hline 0 & $153 \pm 13$ & & $0.0018 \pm 0.00008$ & \\
\hline 1 & $130 \pm 23$ & $126 \pm 25$ & $0.0021 \pm 0.00007$ & $0.0020 \pm 0.00013$ \\
\hline 3 & $78 \pm 21$ & $96 \pm 13$ & $0.0043 \pm 0.00013$ & $0.0041 \pm 0.00010$ \\
\hline 5 & $80 \pm 17$ & $74 \pm 4$ & $0.0048 \pm 0.00012$ & $0.0047 \pm 0.00009$ \\
\hline
\end{tabular}


Table 4. Effect of $\mathrm{AlCl}_{3}$ on the changes in $\mathrm{Al}$ level in endosperm and hull of germinating rice grains and in endosperm of germinating dehulled rice grains. Rice grains or dehulled rice grains were incubated in water ( $\mathrm{pH} 4.0$ ) or $0.5 \mathrm{mM} \mathrm{AlCl}_{3}(\mathrm{pH} 4.0)$. Mean $\pm \mathrm{SD}$, $n=4$. Asterisks indicated that values are significantly different between $\mathrm{H}_{2} \mathrm{O}$ and $\mathrm{AlCl}_{3}$ treatments at $P<0.05$ level determined by Student's t-test.

\begin{tabular}{|c|c|c|c|c|c|c|}
\hline \multirow[t]{2}{*}{$\begin{array}{l}\text { Time } \\
\text { [d] }\end{array}$} & \multicolumn{2}{|c|}{$\begin{array}{l}\text { Rice grains } \\
\mathrm{Al} \text { in hull }\left[\mu \mathrm{g} \mathrm{g}^{-1}(\text { d.m. })\right]\end{array}$} & \multicolumn{2}{|c|}{$\mathrm{Al}$ in endosperm $\left[\mu \mathrm{g} \mathrm{g}^{-1}(\mathrm{~d} . \mathrm{m}).\right]$} & \multicolumn{2}{|c|}{$\begin{array}{l}\text { Dehulled grains } \\
\left.\mathrm{Al} \text { in endosperm [ } \mu \mathrm{g} \mathrm{g}^{-1}(\mathrm{~d} . \mathrm{m} .)\right]\end{array}$} \\
\hline & $\mathrm{H}_{2} \mathrm{O}$ & $\mathrm{AlCl}_{3}$ & $\mathrm{H}_{2} \mathrm{O}$ & $\mathrm{AlCl}_{3}$ & $\mathrm{H}_{2} \mathrm{O}$ & $\mathrm{AlCl}_{3}$ \\
\hline 0 & $3.82 \pm$ & & $2.99 \pm 0.33$ & & $2.33 \pm 0.20$ & \\
\hline 1 & $2.91 \pm$ & $21.85 \pm 1.67^{*}$ & $3.73 \pm 0.51$ & $5.43 \pm 0.81$ & $2.67 \pm 0.10$ & $6.64 \pm 0.18^{*}$ \\
\hline 3 & $2.72 \pm$ & $25.78 \pm 2.76 *$ & $4.00 \pm 0.59$ & $6.34 \pm 1.15$ & $2.68 \pm 0.10$ & $19.82 \pm 1.21 *$ \\
\hline 5 & $2.84=$ & $27.85 \pm 1.50^{*}$ & $4.29 \pm 0.45$ & $7.53 \pm 1.47^{*}$ & $3.23 \pm 0.32$ & $32.13 \pm 1.87 *$ \\
\hline
\end{tabular}

affect reserve mobilization in endosperm of germinating rice grains is possibly attributable to the less amount of $\mathrm{Al}$ in the endosperm. If this suggestion is correct, then $\mathrm{AlCl}_{3}$ is expected to inhibit endosperm mobilization in germinating dehulled rice grains. When dehulled rice grains were treated with $\mathrm{AlCl}_{3}$, it was found that $\mathrm{AlCl}_{3}$ inhibited the decrease in endosperm d.m. and f.m. (Fig. $1 A, B$ ), the decrease in starch and protein contents (Fig. $1 C, E$ ), and the increase in $\alpha$-amylase and protease activities (Fig. 1D,F).

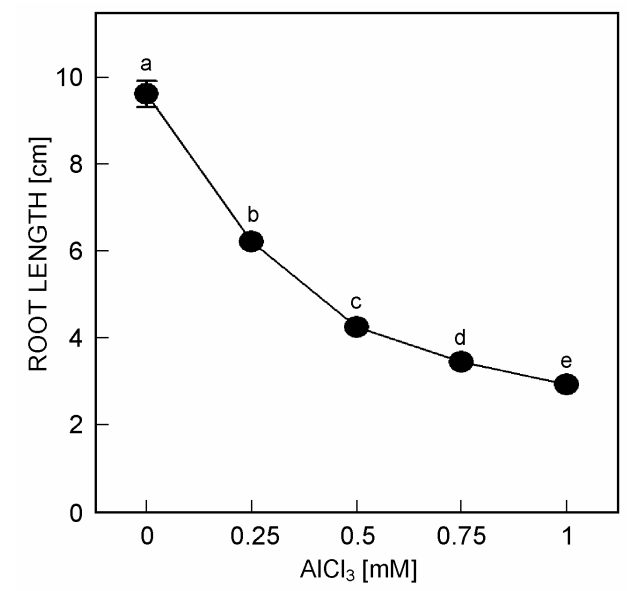

Fig. 2. Effect of $\mathrm{AlCl}_{3}$ on root growth of rice seedlings. Germinating rice grains were treated with different concentrations of $\mathrm{AlCl}_{3}$ (pH 4.0) for $24 \mathrm{~h}$. Means with the same letter are not significantly different at $P<0.05$, according to Duncan's multiple range test.

$\mathrm{Al}$ is known to inhibit root growth (Nishizawa 1995). We also show that $\mathrm{Al}$ inhibits root growth of rice during germination of rice grains (Fig. 2). Mobilization of seed reserves, which occurs during early seed germination, is crucial because it supplies substrates for the proper functioning of different metabolic processes that are
Table 5. Changes in root length of rice seedlings with different treatments. For all treatments, $0.25 \mathrm{mg} \mathrm{dm}^{-3}$ chlorophenicol was added to prevent bacterial growth. Root length was measured 12 h after treatment. Means \pm SD, $n=4$. Means with the same letter are not significantly different at $P<0.05$, according to Duncan's multiple range test.

\begin{tabular}{lll}
\hline $\mathrm{AlCl}_{3}[\mathrm{mM}]$ & Addition & Root length $[\mathrm{cm}]$ \\
\hline 0.0 & 0 & $3.73 \pm 0.08^{\mathrm{a}}$ \\
0.5 & 0 & $3.03 \pm 0.08^{\mathrm{b}}$ \\
0.5 & $15 \mathrm{mM}$ sucrose & $3.03 \pm 0.03^{\mathrm{b}}$ \\
0.5 & $30 \mathrm{mM}$ sucrose & $3.03 \pm 0.03^{\mathrm{b}}$ \\
0.5 & $45 \mathrm{mM}$ sucrose & $3.10 \pm 0.05^{\mathrm{b}}$ \\
0.0 & 0 & $3.34 \pm 0.04^{\mathrm{a}}$ \\
0.5 & 0 & $2.59 \pm 0.05^{\mathrm{b}}$ \\
0.5 & $0.5 \mathrm{mM}$ L-asparagine & $2.56 \pm 0.03^{\mathrm{b}}$ \\
0.5 & $1.0 \mathrm{mM}$ L-asparagine & $2.70 \pm 0.06^{\mathrm{b}}$ \\
0.5 & $3.0 \mathrm{mM}$ L-asparagine & $2.73 \pm 0.10^{\mathrm{b}}$ \\
0.5 & $5.0 \mathrm{mM}$ L-asparagine & $2.66 \pm 0.11^{\mathrm{b}}$ \\
0.0 & 0 & $3.39 \pm 0.02^{\mathrm{a}}$ \\
0.5 & 0 & $2.92 \pm 0.03^{\mathrm{b}}$ \\
0.5 & $0.5 \mathrm{mM}$ L-glutamine & $2.92 \pm 0.02^{\mathrm{b}}$ \\
0.5 & $1.0 \mathrm{mM}$ L-glutamine & $2.87 \pm 0.04^{\mathrm{b}}$ \\
0.5 & $3.0 \mathrm{mM}$ L-glutamine & $2.86 \pm 0.01^{\mathrm{b}}$ \\
0.5 & $5.0 \mathrm{mM}$ L-glutamine & $2.84 \pm 0.06^{\mathrm{b}}$ \\
\hline
\end{tabular}

essential to growth of shoot and roots (Bewley 1997, Pritchard et al. 2002). $\mathrm{AlCl}_{3}$ has no effect on endosperm mobilization in germinating rice grains, thus, the inhibition of root growth by $\mathrm{Al}$ is unlikely to be attributable to lack of products of endosperm mobilization. Because the addition of sucrose, L-glutamine, and L-asparagine did not improve the root growth of seedlings in $\mathrm{AlCl}_{3}$ medium (Table 5), the translocation of sucrose and amino acids from endosperm into root is unlikely inhibited by $\mathrm{AlCl}_{3}$. 


\section{References}

Beevers, L.: Protein degradation and protealytic activity in the cotyledons of pea seeds (Pisum sativum L.). Phytochemistry 7: 1837-1844, 1968.

Bewley, J.D.: Seed germination and dormancy. - Plant Cell 9: 1055-1066, 1997.

Bradford, M.M.: A rapid and sensitive method for the quantitation microgram of protein using the principles of protein-dye binding. - Anal. Biochem. 72: 248-254, 1976.

Hurng, W.P., Kao, C.H.: Loss of starch and increase of $\alpha$-amylase activity in leaves of flooded tobacco plants. Plant Cell Physiol. 34: 531-534, 1993.

Kataoka, T., Furukawa, J., Nakanishi, T.M.: The decrease of extracted apoplast protein in soybean root tip by aluminum treatment. - Biol. Plant. 46: 445-449, 2003.

Lin, C.C., Kao, C.H.: $\mathrm{NaCl}$ stress in rice seedlings: starch mobilization and the influence of gibberellic acid on seedlings growth. - Bot. Bull. Acad. sin. 36: 169-173, 1995.

Matsumoto, H.: Cell biology of aluminum toxicity and tolerance in higher plants. - Int. Rev. Cytol. 200: 1-46, 2000.

Nishizawa, N.: Nutrient absorption of the rice plant. - In:
Matsuo, T., Kumazawa, K., Ishii, R., Ishihara, K., Hirata, H. (ed.): Science of the Rice Plant. Vol. 2. Pp. 244-309. Food and Agriculture Policy Research Center, Tokyo 1995.

Pritchard, S.L., Charlton, W.L., Baker, A., Graham, A.: Germination and storage reserve mobilization are regulated independently in Arabidopsis. - Plant J. 31: 639-647, 2002.

Rinderknecht, H., Wilding, P., Haverback, B.J.: A new method for the determination of $\alpha$-amylase. - Experientia 23: 805, 1967.

Sheoran, I.S., Garg, O.P.: Effect of salinity on the activities of RNase, DNAase and protease during germination and early seedling growth of mung bean. - Physiol. Plant. 44: 171-174, 1978.

Yomo, H., Varner, J.E.: Control of formation of amylase and protease in the cotyledons of germinating peas. - Plant Physiol. 51: 708-713, 1973.

Yu, S.-M., Tzou, W.S., Lo, W.-S., Kuo, Y.-H., Lee, H.-T., Wu, R.: Regulation of $\alpha$-amylase gene expression in germinating seeds and cultured cells of rice. - Gene 122: 247-253, 1992. 